\title{
Analysis of the fifth cell cycle of mouse development
}

\author{
Julia C. Chisholm \\ Department of Anatomy, University of Cambridge, Downing Street, Cambridge, CB2 3DY, U.K.
}

\begin{abstract}
Summary. The 5th cell cycle of mouse development was analysed to determine the lengths of each cell cycle phase. The DNA content of Feulgen-stained blastomere nuclei was measured at various times throughout the cell cycle by microdensitometry. To achieve precise timing of the start of the 5th cell cycle, experiments utilized isolated 16-cell blastomeres and cell pairs obtained by in-vitro division of isolated 8-cell blastomeres. The following estimates were made for a mixed population of polar and apolar 16-cell blastomeres: $G_{1}, \leqslant 2 h ; S, 8-9 h ; G_{2}+M, 2 h$. No significant difference was found in the timing of DNA synthesis between polar and apolar cells or between cell pairs and whole embryos.
\end{abstract}

Keywords: DNA synthesis; fifth cell cycle; mouse embryo

\section{Introduction}

During early embryonic development cell differentiation must be regulated in time as well as in space. In some non-mammalian species it is clear that one important component of temporal regulation is the cell cycle (Satoh \& Ikegami, 1981a, b; Newport \& Kirschner, 1982a, b; Edgar et al., 1986) and in the mouse embryo also there is evidence that at least some early steps in differentiation may relate to specific cell cycles or cell cycle phases (Smith \& McLaren, 1977; Spindle et al., 1985; Howlett, 1986; Garbutt et al., 1987). Such a relationship may involve the measurement of time elapsed in relation to an earlier, time-setting event (e.g. fertilization) by the number of cell cycles undergone since that event. In addition, particular aspects of differentiation may be limited to specific cell cycles or cell cycle phases by a changing cellular receptivity to regulatory signals (see Smith \& Johnson, 1986).

The potential importance of the cell cycle in temporal regulation has resulted in efforts to elucidate the timing of the early cell cycles of mouse development to clarify their relationship to various aspects of differentiation. Attempts to time cell cycles are hampered, however, by the marked and increasing cell cycle asynchrony that exists between and within embryos (Barlow et al., 1972; Kelly et al., 1978; Streffer et al., 1980; Chisholm et al., 1985). The problem of asynchrony can be overcome for the early cell cycles by studying those embryos, within a population, all cells of which show natural synchrony. Using such precisely timed embryos, data have been obtained to supplement earlier results on the lengths of each phase of the first 4 cell cycles (Bolton et al., 1984; Howlett \& Bolton, 1985; Smith \& Johnson, 1986). However, timing techniques using whole embryos are not helpful for analysing the 5 th cell cycle since few 16-cell embryos retain intraembryo cell cycle synchrony and the timing of division from 8 to 16 cells in situ is not easy to observe very precisely. Moreover, the 16-cell embryo contains two distinct subpopulations of cells which differ not only in position, phenotype and fate (reviewed by Johnson et al., 1986a) but also in their cell cycle times. Studies using carefully timed, isolated 16-cell blastomeres and cell pairs suggest that the outer, larger, polar cells have a mean cell cycle time of $12 \mathrm{~h}$ compared to a mean cell cycle of $13-14 \mathrm{~h}$ for the inner, apolar cells (MacQueen \& Johnson, 1983, using HC-CFLP mice; J. C. Chisholm, unpublished data, using MF1 mice). Similar cell cycle times in the intact embryo are suggested from cell counts of inner and outer cell populations in late morulae and early blastocysts (Chisholm 
et al., 1985) although the alternative suggestion that inside cells in situ show a shorter cell cycle than outer cells has been made also (Surani \& Barton, 1984). Clearly outer and inner cells may show different cell cycle characteristics.

Although there are some existing reports on cell cycle phases in the 16-cell embryo (Gamow \& Prescott, 1970; Barlow et al., 1972; Streffer et al., 1980), no attempt has previously been made to time cells accurately from the start of the 5 th cell cycle. The experiments described in this paper utilized isolated blastomeres and cell pairs timed precisely from division to 16 cells. Microdensitometric measurements were made to determine the DNA content of cells at various times throughout the 5 th cell cycle both in mixed populations of outer and inner cells and in relatively pure populations of the two cell types.

\section{Materials and Methods}

Embryo recovery and culture. Female MFl mice (Central Animal Services, University of Cambridge) aged 3-6 weeks were induced to superovulate by intraperitoneal injection of 5-10 i.u. PMSG followed $44-48 \mathrm{~h}$ later by the same dose of hCG. After overnight pairing with HC-CFLP males (Hacking \& Churchill Ltd, Alconbury, Cambs, U.K.) they were inspected the following morning for evidence of mating.

Embryos were collected at the late 8-cell stage at $65-70 \mathrm{~h}$ after hCG by flushing oviducts with Medium 2 containing $4 \mathrm{mg}$ bovine serum albumin $/ \mathrm{ml}$ (BSA; Fulton \& Whittingham, 1978). They were cultured in Falcon plastic dishes in pre-equilibrated Medium 16 containing $4 \mathrm{mg} \mathrm{BSA} / \mathrm{ml}$ (Whittingham, 1971) at $37^{\circ} \mathrm{C}$ in $5 \% \mathrm{CO}_{2}$ in air. Single blastomeres and cell pairs were cultured in Sterilin dishes.

Embryo manipulations and timing. All embryo manipulations were performed on a heated microscope stage at $37^{\circ} \mathrm{C}$. Removal of the zona pellucida was achieved by brief incubation in acid Tyrode's solution (Nicolson et al., 1975). Embryos were disaggregated after 10-15 min incubation in calcium-free Medium 2 containing $6 \mathrm{mg} \mathrm{BSA} / \mathrm{ml}$ by gently blowing them apart using flame-polished micropipettes. Single 8-cell blastomeres were cultured in small groups in microdrops of Medium 16 + BSA and were scored hourly for division to pairs of 16-cell blastomeres (2/16 pairs). Newly formed pairs were pooled and designated $0 \mathrm{~h}$ old. To obtain single 16-cell blastomeres, newly formed $2 / 16$ pairs were disaggregated in calcium-free Medium 16 containing $6 \mathrm{mg} \mathrm{BSA} / \mathrm{ml}$.

To time the 8- to 16-cell transition in intact embryos, late 8-cell zona-intact embryos were placed into individual microdrops of the monoclonal antibody ECCD-1 (Yoshida-Noro et al., 1984) diluted 1:150 in Medium $16+$ BSA. Antibody ECCD-1 is directed against a calcium-dependent cell surface adhesion molecule (Shirayoshi et al., 1983). After antibody-induced decompaction, the embryos were scored hourly for division from 8- to 16-cells and those which completed the transition within $2 \mathrm{~h}$ from division of the first blastomere were washed thoroughly in Medium $2+$ BSA and cultured further. Embryos of 9-15 cells were recognized by the presence of blastomeres of very different sizes whilst 8-and 16-cell embryos consisted of blastomeres of approximately homogeneous sizes.

Quantitative analysis of DNA. Embryos or blastomeres were placed onto acetic acid-cleaned glass slides and a smear from freshly dissected mouse liver was made at the end of each slide to provide diploid (2C) and tetraploid (4C) standards for DNA quantitation. Whole embryos had been preincubated in calcium-free Medium $2+$ BSA for 10-15 min before transfer to the slide, to encourage cells to spread. The slides were air-dried, fixed and stained by the Feulgen reaction (Pearse, 1972) as previously described (Bolton et al., 1984). Slides were stored at $-20^{\circ} \mathrm{C}$ in the dark for up to 10 days before scoring. Nuclear DNA content was assayed using a Vickers M86 scanning microdensitometer by measuring absorption at $560 \mathrm{~nm}$ (Bolton et al., 1984).

\section{Results}

\section{DNA synthesis in pairs of 16-cell blastomeres}

Pairs of 16-cell blastomeres (2/16 pairs) were generated by the in-vitro division of isolated 8-cell blastomeres to enable accurate timing of the start of the 5 th cell cycle. Newly formed $2 / 16$ pairs were distinguished as pairs of unequal- or equal-sized cells to represent polar-apolar and polar-polar cell pairs (Johnson \& Ziomek, 1981).

The DNA content of nuclei of equal- and unequal-sized pairs was measured at times between 0 and $14 \mathrm{~h}$ after division. Results from both types of pair were very similar (Fig. 1). DNA synthesis was evident as early as $1-2 \mathrm{~h}$ after division and showed a steady increase through to $14 \mathrm{~h}$ after 
division (Fig. 1). Plotting values for individual nuclei (Fig. 2) showed that the length of the $G_{1}$ phase was variable; most cells at $0 \mathrm{~h}$ after division had $2 \mathrm{C}$ DNA content although some had already started to replicate their DNA. Moreover, whilst most cells began DNA synthesis within $2 \mathrm{~h}$ after division, it was not until $6 \mathrm{~h}$ after division that all cells appeared to be in S phase. Apparent differences in the length of $G_{1}$ were felt to be real, rather than the result of variability in microdensitometric reading from cells of similar DNA content, because the scatter in 2C DNA readings from the liver standard was small (s.d. $=3-4 \%$ ). However, part of the increase in mean DNA values between $0 \mathrm{~h}$ and $1 \mathrm{~h}$ after division may have been due to decondensation of the DNA since the highly condensed chromatin of newly formed cells often gave readings substantially lower than the 2 C DNA value (data not shown). A similar phenomenon was observed in mitotic cells which frequently gave readings of less than $4 \mathrm{C}$.

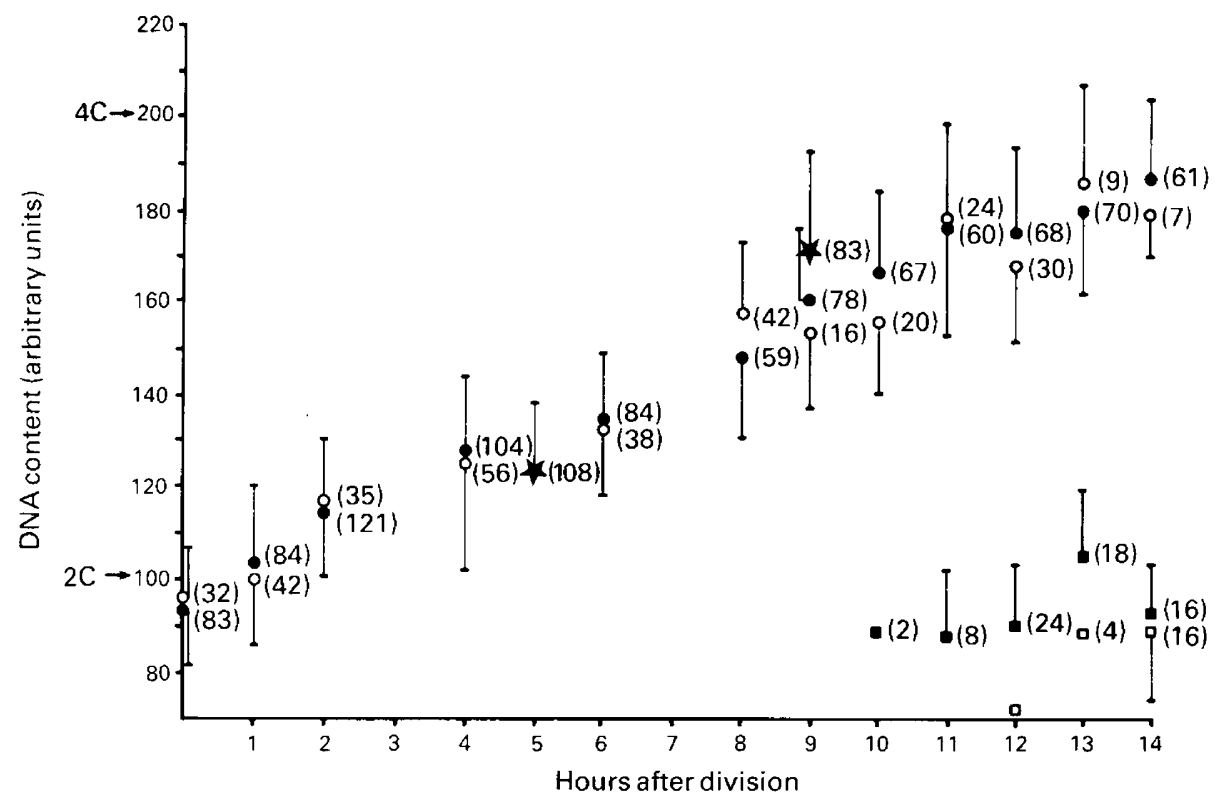

Fig. 1. Mean DNA content in blastomeres of timed 2/16 pairs and 16-cell mouse embryos. $O$, equal-sized pairs; $\square, 1 / 32$ cells from equal-sized pairs; $\bullet$, unequal-sized pairs; $\mathbf{\square}, 1 / 32$ cells from unequal-sized pairs; $\star, 16$-cell embryos timed from division to 16 cells after decompaction in antibody ECCD-1. Numbers in parentheses indicate the number of nuclei scored. Bars show one standard deviation from the mean; $95 \%$ confidence limits for $2 \mathrm{C}$ liver values varied from \pm 6 to \pm 8 arbitrary units on different occasions.

Nuclei with a DNA content approaching $4 \mathrm{C}$ were relatively common at $8 \mathrm{~h}$ after division (but note two atypical cells at $4 \mathrm{~h}$ with DNA values of 190-200, Fig. 2). Mitotic 1/16 cells and newly formed $1 / 32$ cells were first recorded at $10 \mathrm{~h}$ after division (of 68 cells in unequal-sized pairs, 1 was mitotic and 1 had divided; Fig. 1). These results suggested $\mathrm{a}_{2}+\mathrm{M}$ phase of about $2 \mathrm{~h}$ for the first 16-cell blastomeres to divide. The continued rise in mean DNA content towards $4 \mathrm{C}$ among undivided cells in the later part of the cell cycle (Fig. 2) suggested that DNA synthesis was continuing in some cells whilst others were already dividing. From these results, it would appear that $\mathrm{G}_{1}$ is variable but usually short ( $\leqslant 2 \mathrm{~h}$ ), $\mathbf{G}_{2}+\mathbf{M}$ is short (probably around $2 \mathrm{~h}$ ) and that the $S$ phase occupies most of the cell cycle $(8-9 \mathrm{~h})$. 

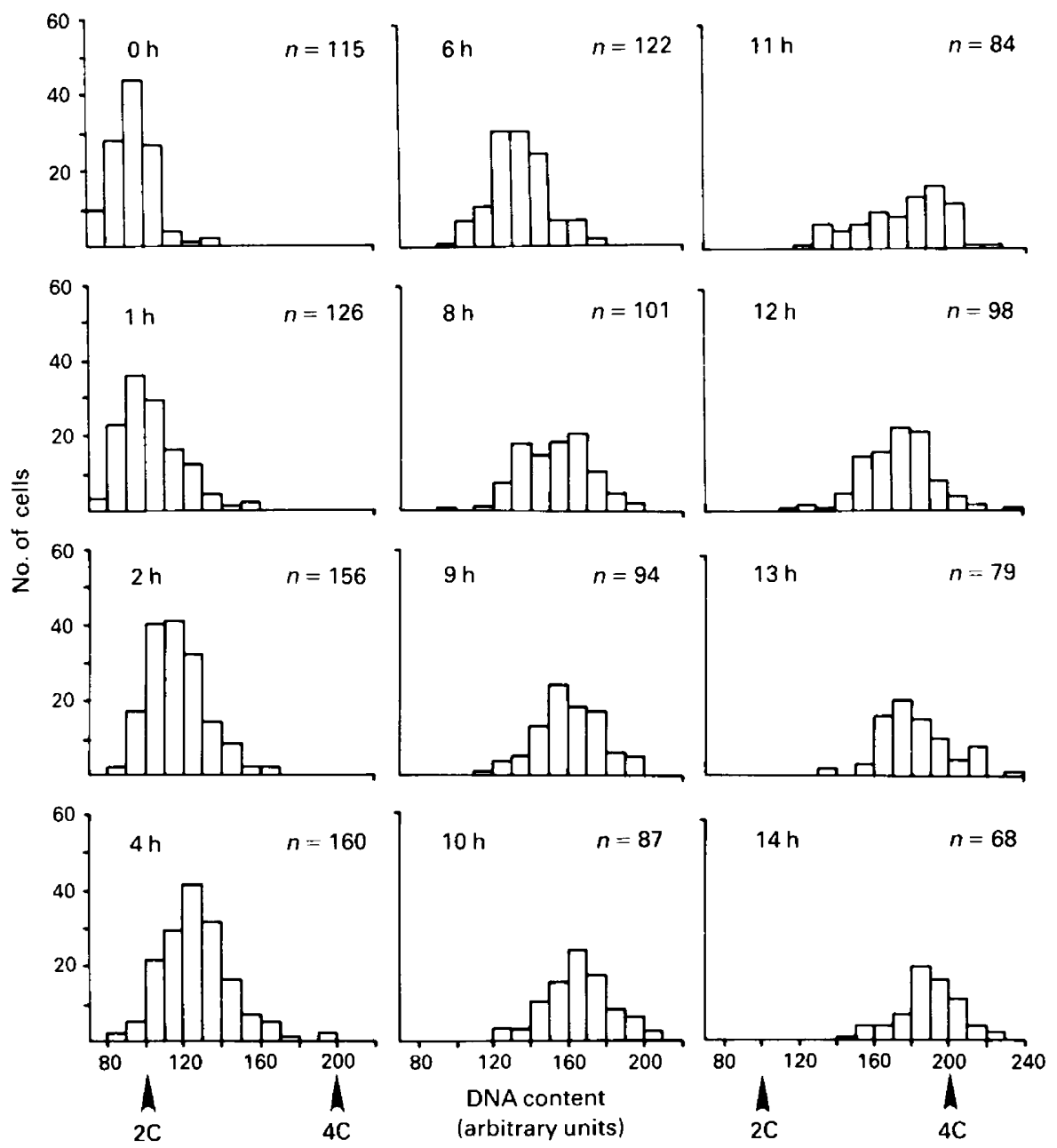

Fig. 2. Nuclear DNA content in timed 2/16 pairs of mouse blastomeres. Frequency distributions of DNA content at different times after division to pairs of 16-cell blastomeres. Results from unequal- and equal-sized pairs are pooled. $n=$ no. of nuclei scored.

\section{DNA synthesis in whole 16-cell embryos}

To confirm that results based on $2 / 16$ pairs were similar to those using intact embryos, late 8-cell embryos were decompacted experimentally by incubation in the monoclonal antibody ECCD-1 (Yoshida-Noro et al., 1984) and observed at hourly intervals for division from 8 to 16 cells. A small number of embryos divided to 16 cells within a 2-h period (i.e. their constituent cells were relatively synchronous) and these were washed free of antibody ECCD-1. Recompaction took place rapidly within 1 or $2 \mathrm{~h}$ after washing out the antibody. The embryos were then cultured on for 4 or $8 \mathrm{~h}$ (i.e. the constituent cells were at $4-6 \mathrm{~h}$ or $8-10 \mathrm{~h}$ after division) and were decompacted in calcium-free Medium $2+$ BSA before making cell spreads for microdensitometry. Antibody ECCD-1 does not affect cell cycle timing in the 8- to 16-cell embryo (Johnson et al., 1986b). Figure 1 shows that mean DNA values were similar to those obtained from $2 / 16$ pairs, indicating that DNA synthesis in $2 / 16$ pairs probably reflects accurately that in whole embryos. 


\section{DNA synthesis in polar and apolar cells}

The finding that unequal- and equal-sized pairs showed no evidence of marked differences in the timing of $S$ phase suggested that DNA synthesis may take a similar time course in polar and apolar cells, even though the 5 th cell cycle of polar cells is on average 1-2 h shorter than that of apolar cells (MacQueen \& Johnson, 1983). To examine DNA synthesis in the two cell types, larger (polar; Ziomek \& Johnson, 1981) and smaller (apolar) cells were isolated from unequal-sized 2/16 pairs at $0 \mathrm{~h}$ and were cultured for various periods of time before fixing for microdensitometry. Isolated cells have cell cycle times indistinguishable from those of cells in 2/16 pairs (MacQueen \& Johnson, 1983) so that any differences in the timing of DNA synthesis within the cell cycle should reflect true differences between polar and apolar cells rather than effects of culture in isolation.

At $0 \mathrm{~h}$ and $2 \mathrm{~h}$ after division, larger and smaller cells had very similar mean DNA values (Fig. 3), suggesting a similar mean length of $\mathrm{G}_{1}$ in both cell types. By $9 \mathrm{~h}$ and $11 \mathrm{~h}$ after division, smaller cells showed a slightly lower mean DNA content than did larger cells, although this difference was not significant statistically $\left(P>0.05, \chi^{2}\right)$ at either time point. Moreover, it was observed that in those $2 / 16$ pairs in which the polar (larger) and apolar (smaller) cells could be distinguished from each other by the elongate shape of the nucleus of the outer, polar enveloping cell, there was no consistent pattern regarding which of the two cells, if either, showed the higher DNA content.

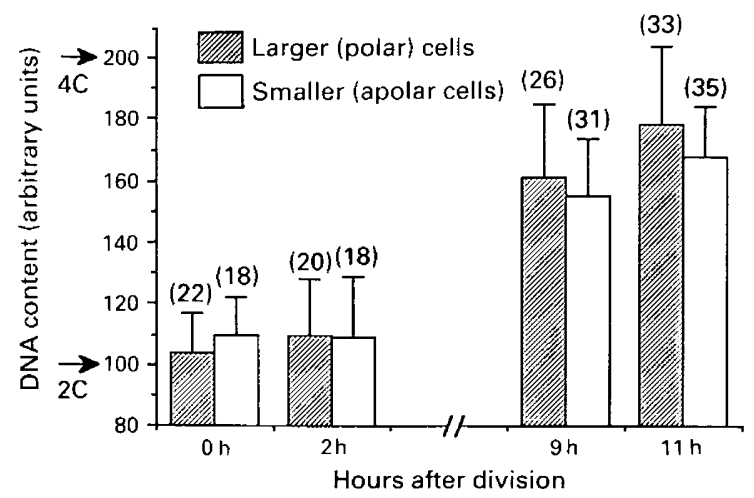

Fig. 3 Mean DNA content in single 16-cell blastomeres. Line bars show one standard deviation from the mean (no. of nuclei scored in parentheses).

\section{Discussion}

The experiments reported in this paper are the first to use synchronized populations of blastomeres to look at the timing of the DNA synthesis in the 5 th cell cycle. The use of $2 / 16$ pairs overcomes the cell cycle asynchrony inherent within the intact embryo and allows precise timing of the start of the 5 th cell cycle. Available evidence suggests that 2/16 pairs provide an accurate model of events in the intact embryo since the cells behave similarly to those of the embryo in a number of ways: they show similar polar and apolar phenotypes, with polar cells flattening over apolar cells (Johnson \& Ziomek, 1981; Ziomek \& Johnson, 1981); cell cycle times are comparable (MacQueen \& Johnson, 1983; Chisholm et al., 1985); timing of cavitation is the same (Garbutt et al., 1987); and they show similar extent and distribution of cytokeratin filaments (Chisholm \& Houliston, 1987). This study now shows that the timing of DNA synthesis in the 5th cell cycle is comparable between cell pairs and whole embryos. Estimates were made of $\leqslant 2 h$ for $G_{1}, 8-9 h$ for $S$ and $2 h$ for $G_{2}+M$. 
The finding that $\mathrm{S}$ phase lasted $8-9 \mathrm{~h}$ agrees well with other reports, based on experiments using different embryo strains and different techniques of quantitation, that the 5 th cell cycle is occupied mostly by the S phase (Gamow \& Prescott, 1970; Barlow et al., 1972; Streffer et al., 1980). In only one of these studies was the length of each phase of the cell cycle estimated (Streffer et al., 1980), by the use of cytofluorometry and autoradiography, and values were given of $3-4 \mathrm{~h}$ for $\mathrm{G}_{1}, 7-8 \mathrm{~h}$ for $\mathrm{S}$ and $2-3 \mathrm{~h}$ for $\mathrm{G}_{2}+\mathrm{M}$. However, the latter estimates were made on a mixed population of embryos at $72 \mathrm{~h}$ post coitum with a mean cell number of around 22 and almost certainly included cells in the 6 th as well as the 5th cell cycles. Since the length of $\mathrm{G}_{1}$ seems to increase at the blastocyst stage (Barlow \& Sherman, 1972; Streffer et al., 1980), cells in their 6th cell cycle may have contributed disproportionately to $G_{1}$, a fact which may explain the longer mean estimate for $G_{1}$ than that of $2 \mathrm{~h}$ reported in the present paper.

Despite a short mean $G_{1}$, considerable variability was noted in the length of $G_{1}$ (up to $6 \mathrm{~h}$; Fig. 2) and this alone could account for most of the variability in the length of the 5th cell cycle among populations of polar or apolar cells. However, a difference in the length of $\mathrm{G}_{1}$ did not account for the known small difference (MacQueen \& Johnson, 1983) in the mean cell cycle lengths of polar and apolar cells (Fig. 3). In the 3 rd and 4 th cell cycles the main component of cell cycle variability occurs in the $G_{2}+M$ phase (Smith \& Johnson, 1986). This late phase may make some contribution to variability in the 5 th cell cycle also, but the results of the present study do not exclude the possibility that DNA synthesis proceeds slightly more slowly in apolar than in polar cells even if differences in DNA content are not statistically significant at any one time.

It has been suggested that the $3 \mathrm{rd}$ and 4 th cell cycles occupy an intermediate position between the 1st and 2nd cell cycles, which are atypical and subject to maternal control, and those that characterize differentiated cells (Smith \& Johnson, 1986). Throughout the first 4 cell cycles the timing of the cell cycle phases changes. In the $3 \mathrm{rd}$ and 4 th cell cycles, $G_{1}$ is increasing in length $(0-1 \cdot 3 \mathrm{~h}$ in the $2 \mathrm{nd}$ cell cycle, $2 \mathrm{~h}$ in the 4 th cell cycle) and $\mathrm{S}$ is stable at $7 \mathrm{~h}(4-7 \mathrm{~h}$ in $1 \mathrm{st}$ and $2 \mathrm{nd}$ cycles) whilst $\mathrm{G}_{2}+\mathrm{M}$ varies (see Smith \& Johnson, 1986). The 5th cell cycle differs from earlier cycles in its increasingly long $S$ phase and variability in $G_{1}$ and therefore is more like that of differentiated somatic cells which show a variable $G_{1}$, constant $S$ and short $G_{2}$ phase (Lloyd et al., 1982). The similarity exists despite the fact that the embryonic cells are not yet terminally differentiated and do not obtain an adult nucleocytoplasmic ratio until the 120-cell stage (M. A. H. Surani, cited in Smith \& Johnson, 1986). However, the 5 th cell cycle does mark an important time in cell differentiation, coinciding with the time that polar and apolar cells of the morula diverge phenotypically and biochemically (reviewed by Johnson, 1985; Fleming, 1986; Johnson et al., 1986a) and begin to synthesize marker proteins characteristic of the emerging trophectoderm and inner cell mass cells (Handyside \& Johnson, 1978). Moreover, the dependence of this molecular differentiation on transcriptional activity (Braude, 1979; Kidder \& McLachlin, 1985) implies control at the level of gene activation. The length of $S$ phase therefore could reflect the important transcriptional events that take place during the 5th cell cycle.

The above findings seem to fit with a pattern in which cell cycles become progressively more like those of somatic, differentiated cells during early development. Something is known of cell cycle patterns in trophectoderm cells of the blastocyst (Barlow et al., 1972; Barlow \& Sherman, 1972), but little such knowledge is available yet for the inner cell mass cells which are the prescursor cells of the somatic tissues.

I thank Dr Martin Johnson and Dr Sarah Howlett for valuable discussions; Dr Johnson for his help in preparation of the manuscript; Sue Pickering, Gin Flach, Martin George and Raith Overill for technical assistance; Dr Mike Bennett at the Plant Breeding Institute, Cambridge, for use of the microdensitometer; and Dr M. Takeichi of the Department of Biophysics, Kyoto University, Japan, for the gift of ECCD-1. The work was supported by a grant from the Medical Research Council to Dr M. H. Johnson and Dr P. R. Braude. The author was in receipt of an MRC studentship. 


\section{References}

Barlow, P. \& Sherman, M.I. (1972) The biochemistry of differentiation of mouse trophoblast: studies on polyploidy. J. Embryol. exp. Morph. 27, 447-465.

Barlow, P., Owen, D.A.J. \& Graham, C. (1972) DNA synthesis in the preimplantation mouse embryo. $J$. Embryol. exp. Morph. 27, 431-445.

Bolton, V.N., Oades, P.J. \& Johnson, M.H. (1984) The relationship between cleavage, DNA replication and gene expression in the mouse 2-cell embryo. Devl Biol. 79, 139-163.

Braude, P.R. (1979) Time-dependent effects of $\alpha$-amanitin on blastocyst formation in the mouse. J. Embryol.exp. Morph. 52, 193-202.

Chisholm, J.C. \& Houliston, E. (1987) Cytokeratin filament assembly in the preimplantation mouse embryo. Development 101, 565-582.

Chisholm, J.C., Johnson, M.H., Warren, P.D., Fleming, T.P. \& Pickering, S.J. (1985) Developmental variability within and between mouse expanding blastocysts and their ICMs. J. Embryol. exp. Morph. 86, 311-336.

Edgar, B.A., Kiehle, C.P. \& Schubiger, G. (1986) Cell cycle control by the nucleo-cytoplasmic ratio in early Drosophila development. Cell 44, 365-372.

Fleming, T.P.(1986) Endocytosis and epithelial biogenesis in the mouse early embryo. Bioessays 4, 105-109.

Fulton, B.P. \& Whittingham, D.G. (1978) Activation of mammalian oocytes by intracellular injection of calcium. Nature, Lond. 273, 149-151.

Gamow, E.I. \& Prescott, D.M. (1970) The cell cycle life during early embryogenesis of the mouse. Expl Cell Res. 59, $117-123$.

Garbutt, C.L., Chisholm, J.C. \& Johnson, M.H. (1987) The establishment of the embryonic-abembryonic axis in the mouse embryo. Development 100, 125-134.

Handyside, A.H. \& Johnson, M.H. (1978) Temporal and spatial patterns of the synthesis of tissue-specific polypeptides in the preimplantation mouse embryo. J. Embryol. exp. Morph. 44, 191-199.

Howlett, S.K. (1986) The effect of inhibiting DNA replication in the one-cell mouse embryo. Roux's Arch. devl Biol. 195, 499-505.

Howlett, S.K. \& Bolton, V.N. (1985) Sequence and regulation of morphological and molecular events during the first cell cycle of mouse embryogenesis. $J$. Embryol. exp. Morph. 87, 175-206.

Johnson, M.H. (1985) Three types of cell interaction regulate the generation of cell diversity in the mouse blastocyst. In The Cell in Contact: Adhesions and Junctions as Morphogenetic Determinants, pp. 27-48. Eds G.M. Edelman \& J-P. Thiery. Neurosciences Institute, New York.

Johnson, M.H. \& Ziomek, C.A. (1981) The foundation of two distinct cell lineages within the mouse morula. Cell. 24, 71-80.

Johnson, M.H., Chisholm, J.C., Fleming, T.P. \& Houliston, E. (1986a) A role for cytoplasmic determinants in the development of the mouse early embryo? J. Embryol. exp. Morph. 97, (Suppl.), 97-121.

Johnson, M.H., Maro, B. \& Takeichi, M. (1986b) The role of cell adhesion in the synchronization and orientation of polarization in 8-cell mouse blastomeres. J. Embryol. exp. Morph. 93, 239-255.
Kelly, S.J., Mulnard, J.G. \& Graham, C.F. (1978) Cell division and cell allocation in early mouse development. J. Embryol. exp. Morph. 48, 37-51.

Kidder, G.M. \& McLachlin, J.R. (1985) Timing of transcription and protein synthesis underlying morphogenesis in preimplantation mouse embryos. Devl Biol. 112, 265-275.

Lloyd, D., Poole, R.K. \& Edwards, S.W. (1982) The Cell Division Cycle. Academic Press, London.

MacQueen, H.A. \& Johnson, M.H. (1983) The fifth cell cycle of the mouse embryo is longer for smaller cells than for larger cells. J. Embryol. exp. Morph. 77, 297-308.

Newport, J. \& Kirschner, M. (1982a) A major developmental transition in early Xenopus embryos. I. Characterization and timing of cellular changes at the midblastula stage. Cell 30, 675-686.

Newport, J. \& Kirschner, M. (1982b) A major developmental transition in early Xenopus embryos. II. Control of onset of transcription. Cell 30, 687-696.

Nicolson, G.L., Yanagimachi, R. \& Yanagimachi, H. (1975) Ultrastructural localisation of lectin-binding sites on the zonae pellucidae and plasma membranes of mammalian eggs. J. Cell Biol. 66, 263-274.

Pearse, A.G.E. (1972) Histochemistry: Theoretical and Applied, Vol. 2, 1230 pp. Churchill Livingstone, London.

Satoh, N. \& Ikegami, S. (1981a) A definite number of aphidicolin-sensitive cell-cyclic events are required for acetylcholinesterase development in the presumptive muscle cells of the ascidian embryos. J. Embryol. exp. Morph. 61, 1-13.

Satoh, N. \& Ikegami, S. (1981b) On the "clock" mechanism determining the time of tissue-specific enzyme development during ascidian embryogenesis. II. Evidence for association of the clock with the cycle of DNA replication. J. Embryol. exp. Morph. 64, 61-71.

Shirayoshi, Y., Okada, T.S. \& Takeichi, M. (1983) The calcium-dependent cell-cell adhesion system regulates inner cell mass formation and cell surface polarization in early mouse development. Cell 35, 631-638.

Smith, R. \& McLaren, A. (1977) Factors affecting the time of formation of the mouse blastocoele. J. Embryol. exp. Morph. 41, 79-92.

Smith, R.K.W. \& Johnson, M.H. (1986) Analysis of the third and fourth cell cycles of mouse early development. J. Reprod. Fert. 76, 393-399.

Spindle, A.I., Nagaro, H. \& Pedersen, R.A. (1985) Inhibition of DNA replication in preimplantation mouse embryos by aphidicolin. J. exp. Zool. 235, 289-295.

Streffer, C., Van Beuningen, D., Molls, M., Zamboglou, N. \& Schulz, S. (1980) Kinetics of cell proliferation in the pre-implanted mouse embryo in vivo and in vitro. Cell Tiss. Kinet. 13, 135-143.

Surani, M.A.H. \& Barton, S.C. (1984) Spatial distribution of blastomeres is dependent on cell division order and interactions in mouse morulae. Devl Biol. 102, 335-343.

Whittingham, D.G. (1971) Culture of mouse ova. J. Reprod. Fert., Suppl. 14, 7-21. 
Yoshida-Noro, C., Suzuki, N. \& Takeichi, M. (1984) Molecular nature of the calcium-dependent cell-cell adhesion system in mouse teratocarcinoma and embryonic cells studied with a monoclonal antibody. Devl Biol. 101, 19-27.
Ziomek, C.A. \& Johnson, M.H.J. (1981) Properties of polar and apolar cells from the 16-cell mouse morula. Roux's Arch. devl Biol. 190, 287-296.

Received 14 October 1987 